\title{
ANÁLISE FUNCIONAL DA PROPRIEDADE INDUSTRIAL NAS RELAÇÕES EMPRESARIAIS CONTEMPORÂNEAS
}

\author{
FUNCTIONAL ANALYSIS OF INDUSTRIAL PROPERTY IN CONTEMPORARY \\ BUSINESS RELATIONS
}

\author{
Querino Mallmann ${ }^{1}$ \\ https://orcid.org/0000-0003-3451-5478 \\ João Pedro Valentim Bastos ${ }^{2}$ \\ https://orcid.org/0000-0001-6950-8572
}

RECEIVED /RECEBIDO 19/01/2020 FEV 2020

APPROVED/APROVADO 22/02/2020 FEV 2020

PUBLISHED /PUBLICADO 28/02/2020 FEV 2020

Editor Responsável: Carla Caldas

Método de Avaliação: Double Blind Review

E-ISSN: 2316-8080

Prefixo do DOI: 10.16928

RESUMO

O trabalho tem como propósito manter e expandir o tema da propriedade intelectual dentre os campos de estudos e investigações do ambiente científico-jurídico brasileiro. Novos desafios são colocados para além dos seus problemas clássicos não superados, mas o avanço científico melhor se dá com as suas bases de sustentação bem definidas e atuais. A constitucionalização dos direitos privados é vista aqui como uma metodologia adequada ao objetivo de estabelecer uma compreensão dos direitos intelectuais em conformidade com o ordenamento atual, que tem na Constituição o seu centro de gravidade. Portanto, valendo-se das referências constitucionais desses direitos, busca-se evidenciar as suas bases de justificação para uma abordagem mais atenta às razões e efeitos das limitações aos direitos intelectuais, explorando a sua função social como forma de se revelar o alcance e a extensão dos seus conteúdos.

Palavras-chave: Propriedade industrial. Constitucionalização. Direito privado. Função social.

\section{ABSTRACT}

The purpose of this paper is to maintain and expand the subject of intellectual property among the fields of studies and investigations of the Brazilian scientific-legal environment. New challenges are placed beyond their classic unsolved problems, but the

\footnotetext{
${ }^{1}$ Doutor em Direito. Professor da Faculdade de Direito e do Mestrado em Direito da Universidade Federal de Alagoas (UFAL), onde ministra a disciplina: "Direito da Propriedade Intelectual". CV: http://lattes.cnpq.br/2702091606416581 - ORCID 0000-0003-3451-5478; e-mail: qmallmann@hotmail.com

$\frac{2}{2}$ Advogado graduado pela Faculdade de Direito de Alagoas - FDA/UFAL. Mestrando pelo Programa de Pós-Graduação em Direito Público da Universidade Federal de Alagoas. ORCID 0000-0001-6950-8572; E-mail: vbastosjp@gmail.com
}

PIDCC, Aracaju/Se, Ano IX, Volume 01 no 01, p.121-153 Fev/2020 | www.pidcc.com.br 
scientific advancement is best with their well-defined and current support bases. The constitutionalization of private law is seen here as a methodology adequate to the objective of establishing an understanding of intellectual rights in accordance with the current legal system, which has its center of gravity in the Constitution. Therefore, using the constitutional references of these rights, it is tried to evidence its bases of justification for a more attentive approach to the reasons and effects of the limitations to the intellectual rights, exploring its social function as a way of revealing the scope and extent of its contents.

Key words: Industrial property. Constitutionalization. Private law. Social function.

SUMÁRIO: 1. Introdução; 2. Metodologia civil-constitucional; 3. Função social nas relações privas; 3.1. Função social da propriedade; 3.2. Função social da empresa; 3.3. Bens de produção, destinação social e propriedade industrial; 4. Compreensão constitucional da propriedade industrial e sua função social; 5. Conclusão; Referências Bibliográficas.

\section{INTRODUÇÃO}

Em um momento de novos constitucionalismos dentro do direito constitucional, muitos campos do direito passaram por transformações e releituras de seus principais institutos jurídicos. Esse trabalho tem o propósito de contribuir para a compreensão da propriedade intelectual dentro desse cenário atual, valendo-se de seu tratamento constitucional para buscar as bases de sustentação para o avanço da sua doutrina. A constitucionalização dos direitos privados é vista aqui como uma metodologia adequada a esse propósito e, em função disso, sobre ela se buscará uma breve compreensão a orientar o desenvolvimento.

A chamada constitucionalização do sistema jurídico impôs releituras e reconstruções aos principais pilares do direito privado na doutrina e na jurisprudência. Como exemplos - e há outros - a propriedade privada, o contrato e a empresa são conduzidos a uma impositiva conformação à nova ordem jurídica que encontra na Constituição o seu eixo e o seu principal vetor axiológico. Nesse contexto, ganharam força e consistência os desenvolvimentos da função social desses institutos. Tais estudos podem ser enquadrados dentro de um esforço doutrinário direcionado à construção de uma nova interpretação jurídica que tenha como ponto de partida as normas 
constitucionais, e que motiva expressões como humanização, personalização, ou repersonalização do direito privado. ${ }^{3}$

No presente trabalho, busca-se inserir a propriedade industrial dentro desse contexto, debruçando-se sobre os dispositivos constitucionais que lhe dão suporte e que lhe servem a uma análise funcionalizada. No entanto, trabalhar a função social de um instituto jurídico importa considerar seus desdobramentos e especificidades, a fim de definir seu significado e particularidades frente a outros institutos. Desse modo, se buscará expor uma compreensão constitucional da natureza jurídica dos direitos de patentes que lhe revele a sua função social, identificando as possíveis relações com a propriedade privada e com a empresa.

Como dito, então, o presente projeto tem como um de seus objetivos manter e expandir o tema da propriedade intelectual dentre os campos de estudos e investigações do ambiente jurídico-acadêmico do país. Tem-se a consciência do fato de que novos desafios são colocados para além dos seus problemas clássicos ainda não inteiramente superados - como atribuição, titularidades, escopo, contratos, limitações, domínio público, sobreposição, gestão coletiva etc. Porém, todo avanço nas compreensões e estudos acerca de um tema, melhor acontece quando se tem encontradas as suas bases de sustentação.

Assim sendo, partindo de uma pesquisa da bibliografia, nacional e estrangeira, bem como da legislação brasileira, adota-se aqui uma abordagem mais atenta às razões e efeitos das limitações aos direitos intelectuais de patentes, explorando o alcance e a extensão dos seus conteúdos em consideração à sua função social, buscando relacioná-la com clássicos institutos jurídicos do direito privado, como a propriedade privada e a empresa.

\section{METODOLOGIA CIVIL-CONSTITUCIONAL}

Compreende-se melhor a influência espinhal que o campo da propriedade intelectual sofre do direito constitucional quando se visualiza um fenômeno característico do novo constitucionalismo: a centralização da Constituição dentro do ordenamento

\footnotetext{
${ }^{3}$ JÚNIOR, José Barros Correia. Função social e a responsabilidade da empresa perante os stakeholders. 2013, p.107. Tese (Doutorado Direito) - Faculdade de Direito de Recife - FDR. Universidade Federal de Pernambuco, Pernambuco.
} 
jurídico. ${ }^{4}$ Esse processo paradigmático tem seu marco temporal bem definido no Brasil justamente com o advento da Constituição de 1988, a qual desbancou o Código Civil da posição que historicamente ocupou. ${ }^{5}$ Bem verdade que a propriedade intelectual já há muito não se encontrava inserida no tratamento do Código Civil, desde antes da Carta de 1988, o que já sinalizava uma tendência da perda de influência do direito civil em alguns âmbitos do direito privado. ${ }^{6}$

Ainda assim, é importante ter em mente que o direito civil sempre forneceu as categorias, os conceitos e as classificações que serviram para a consolidação dos vários ramos do direito privado, e também do direito público. ${ }^{7}$ O Código Civil ocupava posição central dentro do sistema jurídico e possuía a pretensão de abarcar o maior número possível de situações jurídicas particulares em seu diploma. Com a paulatina perda da sua capacidade de completude, microssistemas se formaram ao seu redor, com leis e estatutos disciplinando matérias específicas. Tais diplomas legais, tidos extravagantes, gravitavam em torno do Código Civil, que funcionava como o principal vetor axiológico e interpretativo, com suas normas gerais irradiando por cada microssistema surgido. $\mathrm{O}$ mesmo, de certo, ocorria com as leis de propriedade intelectual.

Contudo, sucede a centralização da Constituição dentro do ordenamento jurídico interno, fazendo surgir o movimento chamado de constitucionalização do direito incluindo o direito privado. A Carta de 1988 é promulgada para ocupar definitivamente o centro gravitacional do ordenamento jurídico, o que, como dito linhas acima, desbancou o Código Civil dessa posição que historicamente ocupou. Com isso, o direito civil passa a ocupar, em estrutura, a mesma posição de todos os outros ramos do direito, em sujeição aos valores e normas consagrados na Constituição.

\footnotetext{
${ }^{4}$ MORAES, Maria Celina Bodin de. A constitucionalização do direito civil e seus efeitos sobre a responsabilidade civil. In: A constitucionalização do direito: fundamentos teóricos e aplicações específicas - org. Cláudio Pereira de Souza Neto e Daniel Sarmento - Rio de Janeiro: Lumen Juris, 2007, p. 233-258.

5 TEPEDINO, Gustavo. Premissas metodológicas para a constitucionalização do Direito Civil. In: RDE - Revista de Direito do Estado, ano 1, $\mathrm{n}^{\mathrm{o}}$ 2:37-53, abr/jun 2006, p. 37-53. Disponível em: http://www.tepedino.adv.br/wpp/wpcontent/uploads/2017/07/Premissas_metodologicas_constitucionalizacao_Direito_Civil_fls_37-53.pdf. Acesso em 01.07.2019.

${ }^{6}$ BARROSO, Luís Roberto. Curso de direito constitucional contemporâneo: os conceitos fundamentais e a construção do novo modelo - $4^{\mathrm{a}}$ ed. - São Paulo: Saraiva, 2013, p. 389.

${ }^{7}$ LÔBO, Paulo. Novas perspectivas da constitucionalização do direito civil. Jus Navigandi, Teresina, ano 18 (/revista/edições/2013), p. 02. Disponível em: <http://jus.com.br/artigos/25361>. Acesso em: 01 jun. 2019.
} 
Tem-se, então, o fenômeno da "plena vinculação e aplicabilidade direta dos princípios e normas constitucionais nas relações privadas", 8 o que se dá como consequência do mesmo contexto de mudança vivida para um paradigma social. ${ }^{9}$ Portanto, inerente à constitucionalização do direitos privado, está a força normativa da constituição, que revelará "a extensão de sua aplicabilidade e eficácia, fator crucial para a concreção dos propósitos constitucionais", ${ }^{10}$ e com a qual se espera extrair das normas constitucionais todo o efeito transformador para o qual se propõem. ${ }^{11}$

Até aí, tem-se a constitucionalização do direito como um fenômeno histórico, um movimento havido com o que se convencionou chamar de novo constitucionalismo, ou constitucionalismo contemporâneo, que, como dito linhas acima, tem na Constituição de 1988 o seu marco temporal no Brasil. ${ }^{12}$ Mas como movimento histórico, acarreta uma necessária mudança de postura dos intérpretes e aplicadores do direito, sobretudo em seus ramos privatísticos. Como afirma Paulo Lôbo, “impõe-se ao intérprete e aos aplicadores do direito a imensa tarefa de interpretar o Código Civil em conformidade com os valores e princípios constitucionais". ${ }^{13} \mathrm{Na}$ verdade, diversos institutos jurídicos dos mais diversos campos específicos do direito passaram por releituras e reconstruções, pela doutrina e pela jurisprudência, na busca pela realização e efetivação da Constituição, pela conformação do ordenamento jurídico aos valores do seu mais novo centro de gravidade.

Aqui, a constitucionalização do direito privado já se assume como uma metodologia de interpretação e aplicação do direito. ${ }^{14}$ Nesse particular, percebe-se que

\footnotetext{
${ }^{8}$ LÔBO, Paulo. Direito Civil: parte geral - 4a ed. - São Paulo: Saraiva, 2013, p 49.

${ }^{9}$ LÔBO, Paulo. Direito Civil: parte geral - 4a ed. - São Paulo: Saraiva, 2013, p 56.

10 TOLEDO, Gastão Alves de. O direito constitucional econômico e sua eficácia - Rio de Janeiro: Renovar, 2004, p. 62.

${ }^{11}$ SARMENTO, Daniel. Direitos fundamentais e relações privadas $-2^{\mathrm{a}}$ ed., 3.tir. - Rio de Janeiro: Lumen Juris, 2010, p. 57.

12 BARROSO, Luís Roberto. A razão sem voto: o Supremo Tribunal Federal e o governo da maioria. In: A razão sem voto: diálogos constitucionais com Luís Roberto Barroso - org. Oscar Vilhena Vieira e Rubens Glezer. São Paulo: Saraiva, 2017. p. 28.

${ }^{13}$ LÔBO, Paulo. Novas perspectivas da constitucionalização do direito civil. Jus Navigandi, Teresina, ano 18 (/revista/edições/2013), p. 09. Disponível em: <http://jus.com.br/artigos/25361>. Acesso em: 01 jun. 2019.

${ }^{14}$ LÔBO, Paulo. Metodologia do Direito Civil Constitucional. In: Direito Civil Constitucional - A ressignificação da função dos institutos fundamentais do direito civil contemporâneo e sua consequências / Organizadores: Carlos Eduardo Pianovski Ruzyk; Eduardo Nunes de Souza; Joyceane Bezerra de Menezes; Marcos Ehrhardt Junior - Florianópolis: Conceito Editorial, 2014. P. 19-31; e TEPEDINO, Gustavo. Premissas metodológicas para a constitucionalização do Direito Civil. In: RDE - Revista de Direito do Estado, ano 1, $\mathrm{n}^{\mathrm{o}}$ 2:37-53, abr/jun 2006, p. 37-53. Disponível em: http://www.tepedino.adv.br/wpp/wp-
} 
com a releitura constitucional da propriedade intelectual, chega-se a uma compreensão mais exata dos seus direitos. Abandona-se uma visão exclusivamente privatística e egoística, centrada nos interesses dos titulares de exclusivas, para se exaltar as suas bases de justificação direcionadas à consecução de interesses coletivos. Evidencia-se a compreensão de objetivos primários - finalísticos - e secundários - instrumentais - da propriedade intelectual, cada qual abrigando interesses diversos.

Como afirma Paulo Lôbo, a fundamentação constitucional do direito privado deve ser constante em sua aplicação. ${ }^{15}$ Essa constatação fulmina qualquer pretensão de auto suficiência de um ramo jurídico específico e, no caso da propriedade intelectual, é evidenciada com os comandos constitucionais que impuseram balizas dentro das quais se impôs a construção da normatização interna referente aos direitos intelectuais. A interpretação e aplicação dos institutos da propriedade intelectual deve recorrer necessariamente aos seus fundamentos constitucionais que, como será visto, expressam fielmente as suas bases de justificação filosófica, por assim dizer.

\section{FUNÇÃO SOCIAL NAS RELAÇÕES PRIVADAS}

Como visto até aqui, a constitucionalização do direito privado é resultado de uma nova formatação do sistema jurídico que redefine, notadamente, os papeis e posições da Constituição e do Código Civil. Em resumo, buscou-se dizer até aqui que essa nova formatação se insere no contexto maior do "novo constitucionalismo", que, contudo, não possui exata conceituação, sendo antes um movimento histórico dado em direção a uma nova atitude diante do estudo e desenvolvimento do Direito, com novas disposições diante da interpretação e aplicação das normas jurídicas. ${ }^{16}$

A normatividade da Constituição é um marco teórico e ao mesmo tempo uma das principais características desse novo momento, responsável pela constitucionalização do direito e pelo desenvolvimento de uma nova dogmática da interpretação constitucional e

\footnotetext{
content/uploads/2017/07/Premissas_metodologicas_constitucionalizacao_Direito_Civil_fls_37-53.pdf. Acesso em 01.07.2019.

${ }^{15}$ LÔBO, Paulo. Novas perspectivas da constitucionalização do direito civil. Jus Navigandi, Teresina, ano 18 (/revista/edições/2013), p. 09. Disponível em: <http://jus.com.br/artigos/25361>. Acesso em: 01 jun. 2019.

${ }^{16}$ KRELL, Andreas Joachim. Entre desdém teórico e aprovação na prática: os métodos clássicos de interpretação jurídica. In: Revista de Direito GV. São Paulo, vol. 10 n. 1, jan/jun, 2014, p. 295-320.
}

PIDCC, Aracaju/Se, Ano IX, Volume 01 no 01, p.121-153 Fev/2020 | www.pidcc.com.br 
de todo o direito infraconstitucional, este em conformidade com a Constituição. ${ }^{17}$ É dentro desse contexto que ganharam força e consistência os estudos e desenvolvimentos da função social dos mais diversos institutos jurídicos do direito privado, como esforço doutrinário direcionado à construção de uma nova interpretação jurídica que tenha como ponto de partida as normas constitucionais. Nesse sentido, temos hoje desenvolvimentos a respeito das funções sociais da propriedade, do contrato, da família, da empresa e de outros institutos, a motivar expressões como humanização, personalização ou repersonalização do direito privado. ${ }^{18}$

No presente trabalho, busca-se inserir a propriedade industrial dentro desse contexto, debruçando-se sobre os dispositivos constitucionais que lhe dão suporte e que lhe servem a uma análise funcionalizada. Em suma, também o campo da propriedade industrial deve estar atento para o fato de que "os processos de formação de ambientes de inovação que deram certo são aqueles que têm a melhoria da vida das pessoas como o seu objetivo maior. Processos em que o ser humano é desrespeitado tendem a falir". ${ }^{19}$ Direitos intelectuais como patentes e desenhos industriais se encontram inseridos em um ramo jurídico mais amplo reconhecido pelo nome de "propriedade industrial", comumente tratada como uma das diferentes espécies de propriedade privada. Busca-se, então, esclarecer a compreensão da natureza jurídica desses direitos a partir de uma análise funcionalizada dentro do contexto de relação com a propriedade e com a empresa.

Dentro desse contexto relacional, portanto, antes de se chegar à análise funcional da propriedade industrial, opta-se por estabelecer breves compreensões acerca das

\footnotetext{
${ }^{17}$ BARROSO, Luís Roberto. A razão sem voto: o Supremo Tribunal Federal e o governo da maioria. In: A razão sem voto: diálogos constitucionais com Luís Roberto Barroso - org. Oscar Vilhena Vieira e Rubens Glezer. São Paulo: Saraiva, 2017. p. 28.

18 JÚNIOR, José Barros Correia. Função social e a responsabilidade da empresa perante os stakeholders. 2013, p.107. Tese (Doutorado Direito) - Faculdade de Direito de Recife - FDR. Universidade Federal de Pernambuco, Pernambuco.

19 ROCHA, José Cláudio; ALVES, Aliana; SANTOS, Gilberto Batista. Direito Contemporâneo, propriedade intelectual e o novo marco legal para a ciência, tecnologia e inovação. In: Revista de Propriedade -Intelectual, Direito Contemporâneo e Constituição - PIDCC - Aracaju/SE, Ano VIII, Vol. 13, $\mathrm{n}^{\mathrm{o}}$ 03, p. 187-206, Out/2019. P. 203. Disponível em: http://pidcc.com.br/br/component/content/article/2-uncategorised/364-direito-contemporaneopropriedade-intelectual-e-o-novo-marco-legal-para-a-ciencia-tecnologia-e-inovacao. Acesso em:
} 26.02.2020 
funções sociais da propriedade privada, dos bens de produção e da empresa, de modo a clarificar as especificidades e relações entre tais institutos e suas funções sociais.

\subsection{FUNÇÃO SOCIAL DA PROPRIEDADE}

A opção por falar brevemente a respeito da função social da propriedade privada nos leva a realizar um salto por sobre a origem e evolução do instituto, focando em uma compreensão atual que parta da ordem constitucional de 1988. Esta, em seu artigo $5^{\circ}$, XXII, garante o direito à propriedade, estabelecendo, contudo, no inciso seguinte, XXIII, que a "propriedade atenderá à sua função social". ${ }^{20} \mathrm{O}$ constituinte adotou a mesma estratégia no artigo 170, estabelecendo, dentre os princípios da ordem econômica, a propriedade, no inciso II, e a sua função social, no inciso III.

Com esse cenário no texto constitucional, Gustavo Tepedino afirma que na história brasileira, nunca se deu à função social um "tratamento tão amplo e tão concretizante como o que se vê na atual Constituição", ${ }^{21}$ pois se escapou à "generalidade e abstração que marcavam a matéria nas Constituições anteriores". ${ }^{22}$ Desse cenário também que se percebe inevitavelmente que a garantia de propriedade não se faz presente no direito brasileiro, caso não se atenda a sua função social. Isso porque sua interpretação como "mera recomendação ao legislador, e não como vinculação jurídica efetiva, tanto do Estado quanto dos particulares, é de ser expressamente repelida", ${ }^{23}$ já que a Constituição expressamente determina em seu artigo $5^{\circ}, \S 1^{\circ}$, que as normas definidoras dos direitos e garantias fundamentais têm aplicação imediata. ${ }^{24}$

\footnotetext{
${ }^{20}$ BRASIL. Constituição Federal de 1988, Art. $5^{\circ}$ : todos são iguais perante a lei, sem distinção de qualquer natureza, garantindo-se aos brasileiros e aos estrangeiros residentes no País a inviolabilidade do direito à vida, à liberdade, à igualdade, à segurança e à propriedade, nos termos seguintes: [...] XXII - é garantido o direito de propriedade; XXIII - a propriedade atenderá a sua função social.

${ }^{21}$ TEPEDINO, Gustavo; SCHREIBER, Anderson. A garantia da propriedade no direito brasileiro. In: Revista da Faculdade de Direito de Campos, Ano VI, nº 6, Junho de 2005, p. 101-120. Disponível em: http://fdc.br/Arquivos/Mestrado/Revistas/Revista06/Docente/04.pdf. Acesso em: 17.07.2019.

22 TEPEDINO, Gustavo; SCHREIBER, Anderson. A garantia da propriedade no direito brasileiro. In: Revista da Faculdade de Direito de Campos, Ano VI, no 6, Junho de 2005, p. 101-120. Disponível em: http://fdc.br/Arquivos/Mestrado/Revistas/Revista06/Docente/04.pdf. Acesso em: 17.07.2019.

${ }^{23}$ COMPARATO, Fábio Konder. Direitos e deveres fundamentais em matéria de propriedade. In: Revista CEJ, Vol. 1, n. 3, set./dez, 1997. Disponível em: http://www.jf.jus.br/ojs2/index.php/revcej/article/view/123/166. Acesso em: 17.07.2019.

${ }^{24}$ BRASIL. Constituição Federal de 1988, Art. $5^{\circ}$ : todos são iguais perante a lei, sem distinção de qualquer natureza, garantindo-se aos brasileiros e aos estrangeiros residentes no País a inviolabilidade do direito à vida, à liberdade, à igualdade, à segurança e à propriedade, nos termos seguintes: [...] § $1^{\circ}$ As normas definidoras dos direitos e garantias fundamentais têm aplicação imediata.
} 
Anderson Schreiber alerta que dentro do "próprio conceito de função social da propriedade permanece ainda alguma incerteza". ${ }^{25}$ É fato que a ideia da função social veio contrapor uma concepção excessivamente individualista e absolutista do direito de propriedade, originada nos ideais liberais mais clássicos consagrados no Código de Napoleão. Contudo, deve-se buscar evitar um conteúdo ideológico sugerido por essa contraposição que leve a uma ameaça ao próprio direito de propriedade privada; a ideia de função social não surge e se desenvolve com a finalidade de extinguir a propriedade privada.

Como dito, o texto constitucional vigente escapou ao tratamento abstrato da função social da propriedade, esmiuçando seu conteúdo ao longo de toda a Carta de 1988, como por exemplo, no artigo $182, \S \S 2^{\circ}$ e $4^{\mathrm{o}},{ }^{26}$ e o artigo 186, incisos I, II, III e IV. ${ }^{27}$ Também o legislador ordinário cumpriu a tarefa de concretizar a função social da propriedade em diversos diplomas legislativos, a exemplo do Código Civil.

Porém, em linhas gerais, seguindo os propósitos do presente trabalho, arriscando uma definição da função social da propriedade - posto constituir uma ideia complexa -, temos que seu desenvolvimento não se dá como princípio contraposto ao direito de propriedade, de modo a contrabalanceá-lo. É, na verdade, uma releitura do direito de

\footnotetext{
${ }^{25}$ SCHREIBER, Anderson. Função social da propriedade na prática jurisprudencial brasileira, p. 03. Disponível em: http://sdls.com.br/uploads/files/2018/06/funcao-social-da-propriedade-na-praticajurisprudencial-brasileira.pdf. Acesso em: 17.07.2019.

${ }^{26}$ BRASIL. Constituição Federal de 1988 Art. 182. A política de desenvolvimento urbano, executada pelo Poder Público municipal, conforme diretrizes gerais fixadas em lei, tem por objetivo ordenar o pleno desenvolvimento das funções sociais da cidade e garantir o bem- estar de seus habitantes. [...] § $2^{\circ} \mathrm{A}$ propriedade urbana cumpre sua função social quando atende às exigências fundamentais de ordenação da cidade expressas no plano diretor. [...] $\S 4^{\circ}$ É facultado ao Poder Público municipal, mediante lei específica para área incluída no plano diretor, exigir, nos termos da lei federal, do proprietário do solo urbano não edificado, subutilizado ou não utilizado, que promova seu adequado aproveitamento, sob pena, sucessivamente, de: I - parcelamento ou edificação compulsórios; II - imposto sobre a propriedade predial e territorial urbana progressivo no tempo; III - desapropriação com pagamento mediante títulos da dívida pública de emissão previamente aprovada pelo Senado Federal, com prazo de resgate de até dez anos, em parcelas anuais, iguais e sucessivas, assegurados o valor real da indenização e os juros legais.

${ }^{27}$ BRASIL. Constituição Federal de 1988 Art. 186. A função social é cumprida quando a propriedade rural atende, simultaneamente, segundo critérios e graus de exigência estabelecidos em lei, aos seguintes requisitos: I - aproveitamento racional e adequado; II - utilização adequada dos recursos naturais disponíveis e preservação do meio ambiente; III - observância das disposições que regulam as relações de trabalho; IV - exploração que favoreça o bem-estar dos proprietários e dos trabalhadores.
} 
propriedade que atinge nuclearmente a sua função, acabando por remodelar a sua estrutura. $^{28}$

Desse modo, a função social não se opõe ao direito de propriedade, de modo a negar-lhe sua existência, esvaziando seu conteúdo ou oprimindo seu gozo por parte de seu titular. A função social compõe o direito de propriedade e a ela intrinsecamente pertence. Como afirma Fábio Konder Comparato, a função social impõe não esquecer que "todo direito subjetivo se insere numa relação entre sujeito ativo e sujeito passivo". ${ }^{29}$ Ou seja, reconhecer um direito implica necessariamente o reconhecimento de um dever correlato. Logo, o direito fundamental de propriedade provoca a existência de deveres fundamentais correlacionados.

Com isso, a propriedade se transmuda de um direito absoluto do proprietário para uma situação jurídica subjetiva que abarca direitos e deveres igualmente positivos, ou seja, atribuídos ao titular do direito de propriedade e a ele impositivos; ${ }^{30}$ a função social, como norma jurídica, é cogente. Daí a compreensão da função social que afasta a ideia de restrições negativas ao exercício do direito de propriedade, externas ao proprietário. Aliás, tal distinção é de fundamental importância. ${ }^{31}$

Uma propriedade que atende a sua função social, portanto, deve ser vista como um direito cuja função abarca agora interesses sociais que devem ser atendidos como forma de, sobretudo, realizar e efetivar a Constituição da República. Uma funcionalização social é, então, uma funcionalização à ordem constitucional atual, que ampliou o espaço dos interesses coletivos ao elevar, como fundamentos da República, a dignidade da pessoa humana e a solidariedade. ${ }^{32}$ Aos clássicos interesses individuais do proprietário - de uso, gozo e disposição do bem -, a ordem jurídica reconheceu a complementariedade de

\footnotetext{
${ }^{28}$ TEPEDINO, Gustavo; SCHREIBER, Anderson. A garantia da propriedade no direito brasileiro. In: Revista da Faculdade de Direito de Campos, Ano VI, n 6, Junho de 2005, p. 101-120. Disponível em: http://fdc.br/Arquivos/Mestrado/Revistas/Revista06/Docente/04.pdf. Acesso em: 17.07.2019.

${ }^{29}$ COMPARATO, Fábio Konder. Direitos e deveres fundamentais em matéria de propriedade. In: Revista CEJ, Vol. 1, n. 3, set./dez, $1997 . \quad$ Disponível em: http://www.jf.jus.br/ojs2/index.php/revcej/article/view/123/166. Acesso em: 17.07.2019.

${ }^{30}$ SCHREIBER, Anderson. Função social da propriedade na prática jurisprudencial brasileira, p. 06. Disponível em: http://sdls.com.br/uploads/files/2018/06/funcao-social-da-propriedade-na-praticajurisprudencial-brasileira.pdf. Acesso em: 17.07.2019.

${ }_{31}$ COMPARATO, Fábio Konder. Função Social da propriedade dos bens de produção. In: Revista de Direito Mercantil, . $^{\circ}$ 63. 6 em: https://edisciplinas.usp.br/pluginfile.php/2297584/mod_resource/content/1/COMPARATO\%2C\%20F.\%2 0C.\%20Funcao\%20social\%20da\%20propriedade\%20dos\%20bens\%20de\%20producao.pdf. Acesso em: 17.07.2019.

32 ALMEIDA, Maria Christina de. A função social da empresa na sociedade contemporânea: perspectivas e prospectivas. In: Argumentum - Revista de Direito n.3 -2003 - UNIMAR. Disponível em: http://ojs.unimar.br/index.php/revistaargumentum/article/viewFile/697/348. Acesso em: 17.07.2019.
} 
interesses metaindividuais, coletivos. ${ }^{33}$ Ressalte-se, assim, a ideia de complementariedade entre tais ordens de interesses, e não de oposição.

Uma atenta interpretação dos princípios da ordem econômica positivados no texto constitucional nos leva à conclusão de que os interesses metaindividuais conformam os interesses individuais, enquanto estes nos levam à realização daqueles. A ordem jurídica elegeu o livre mercado como regime econômico adotado pelo Estado brasileiro, com o qual se espera atingir o desenvolvimento nacional, econômico e social. Em suma, os interesses sociais e coletivos da sociedade brasileira, acreditou o constituinte, serão realizados pelo pleno e eficaz funcionamento da economia, sob o sistema livre de mercado, onde a propriedade privada assume imprescindibilidade.

Então, a função social compõe o direito de propriedade, não havendo contraposição. Ela implica no reconhecimento de interesses metaindividuais, ao lado dos já consagrados interesses individuais do proprietário, a serem satisfeitos pelo exercício do direito de propriedade. Assim, o proprietário, no uso, gozo e disposição de seu bem, deverá satisfazer seus interesses de um modo atento aos interesses sociais, contribuindo, assim, para a sua realização. Por fim, o proprietário permanece como titular do direito de propriedade e beneficiário imediato das prerrogativas desse direito, e, nessa condição, titular também dos deveres e ônus intersubjetivamente relacionados com o direito de propriedade.

\subsection{FUNÇÃO SOCIAL DA EMPRESA}

Como dito até aqui, a constitucionalização do direito é, antes de tudo, um movimento histórico relacionado ao novo tempo da sociedade civil contemporânea, a qual demandou um novo perfil de Estado correlato a uma nova ordem jurídica. Nesta nova ordem, Direito Público e Direito Privado interpenetram-se e as relações jurídico-sociais sofrem alterações no seu pensar e no seu dialogar.

Estas mudanças exigiram - e exigem - um novo comportamento do intérprete jurídico, donde se falar da constitucionalização do direito privado também como uma

33 JÚNIOR, José Barros Correia. Função social e a responsabilidade da empresa perante os stakeholders. 2013, p.89. Tese (Doutorado Direito) - Faculdade de Direito de Recife - FDR. Universidade Federal de Pernambuco, Pernambuco. 
metodologia de interpretação jurídica, uma leitura hermenêutica atual que se volte à aplicação direta e eficaz da ordem constitucional brasileira também nas relações privadas.

Nesse cenário, foi dito até aqui, pilares do direito privado vêm sendo revisados e a ideia de função social dos direitos ganhou, então, fôlego e maior adesão na doutrina e na jurisprudência. No item anterior, arriscou-se definir suscintamente a função social da propriedade, constatando menções expressas desse instituto no texto constitucional, o qual, inclusive, direciona em muitos pontos a interpretação do seu conteúdo, fugindo a uma previsão abstrata e genérica. Também nessa tarefa viu-se como a Constituição nos leva aos princípios da ordem econômica, e como uma compreensão da propriedade privada que contemple a sua função social importa no reconhecimento da escolha do constituinte brasileiro por um regime econômico de livre mercado.

$\mathrm{Na}$ sociedade civil contemporânea, da qual se fala nesse trabalho, instalou-se o perfil de estado social desenhado na ordem constitucional inaugurada com a Carta de 1988, onde ampliou-se o espaço de interesses coletivos, elevando ao ponto mais alto do sistema jurídico e social a dignidade da pessoa humana, como fundamento da República. A solidariedade ganha, assim, destaque, e os direitos sociais foram multiplicados no texto constitucional ao lado das garantias individuais fundamentais. Contudo, nessa mesma sociedade contemporânea foi instalado também, de modo correlato, o regime econômico de livre mercado, igualmente desenhado na ordem constitucional vigente com os valores sociais do trabalho e da livre iniciativa compondo, do mesmo modo, os fundamentos da República.

No regime econômico de livre mercado, foi dito, a propriedade privada é imprescindível, assim como o regime livre de trocas que tem nos contratos a sua forma jurídica mais axiomática. Nesse ambiente, a empresa figura como a atividade econômica que guarda, justamente, o propósito destacado de produção e circulação de bens e serviços. A empresa é, portanto, e por definição, ${ }^{34}$ a principal atividade de realização do regime econômico de livre mercado, adotado pela ordem constitucional brasileira. Nas palavras de José Barros Jr., a empresa é "o centro polarizador da atividade econômica

\footnotetext{
${ }^{34}$ BRASIL. Código Civil de 2002, Art. 966: Considera-se empresário quem exerce profissionalmente atividade econômica organizada para a produção ou a circulação de bens ou de serviços.
} 
moderna. Através dela age o poder econômico e através dela se realizam as relações econômicas". 35

Recorrendo, mais uma vez, às palavras do professor, "por ser o polo convergente de todo o poder econômico moderno, é que se pode afirmar que é justamente na empresa que a função social da propriedade mais se destaca". ${ }^{36}$ Assim sendo, também a empresa, enquanto instituto jurídico, passa por releituras motivadas pela constitucionalização do direito privado. Também no ramo jurídico empresarial se fala em uma função social da empresa, que, no entanto, ao contrário do que ocorre com a função social da propriedade privada, não se encontra expressamente referenciada no texto constitucional ou no direito infraconstitucional. Registre-se, aliás, respeitáveis posições contrárias a tal ideia, como a de Fábio Konder Comparato, quem afirma que esse pilar do direito privado "não comporta deveres de prestação de serviços sociais, incompatíveis com a própria natureza da empresa, em nosso sistema econômico, em sua qualidade de entidade direcionada, primariamente, à produção de lucros". ${ }^{37}$

Em que pese a ausência de disposições expressas no texto constitucional e no direito infraconstitucional, à função social da empresa pode-se chegar, na ordem constitucional, através da sua compreensão enquanto propriedade dinâmica, recorrendose à classificação de Eros Roberto Grau; ${ }^{38}$ e na ordem infraconstitucional, enquanto atividade, dada à sequência de atos e negócios jurídicos direcionados ao seu objetivo final, ou seja, dada à realização de contratos em cadeia. Os contratos devem obedecer à sua função social, conforme artigo 421, do Código Civil. ${ }^{39}$

Focando na função social da empresa na ordem constitucional, adquire importância a noção de propriedade dinâmica, a qual teria se referido o constituinte no

\footnotetext{
35 JÚNIOR, José Barros Correia. Função social e a responsabilidade da empresa perante os stakeholders. 2013, p.98. Tese (Doutorado Direito) - Faculdade de Direito de Recife - FDR. Universidade Federal de Pernambuco, Pernambuco.

36 JÚNIOR, José Barros Correia. Função social e a responsabilidade da empresa perante os stakeholders. 2013, p.102. Tese (Doutorado Direito) - Faculdade de Direito de Recife - FDR. Universidade Federal de Pernambuco, Pernambuco.

${ }^{37}$ COMPARATO, Fábio Konder. Direitos e deveres fundamentais em matéria de propriedade. In: Revista CEJ, Vol. 1, n. 3, set./dez, 1997. Disponível em: http://www.jf.jus.br/ojs2/index.php/revcej/article/view/123/166. Acesso em: 17.07.2019.

${ }^{38}$ GRAU, Eros Roberto. A ordem econômica na Constituição de 1988. São Paulo: Malheiros, 2000, p. 257-ss.

${ }^{39}$ BRASIL. Código Civil de 2002, Art. 421: A liberdade de contratar será exercida em razão e nos limites da função social do contrato, observado o disposto na Declaração de Direitos de Liberdade Econômica.
} 
artigo 170 da constituição, incisos I e II, aparentemente repetindo a si mesmo quando da primeira passagem relativa à propriedade e sua função social no artigo $5^{\circ}$, incisos XXII e XXIII. "Aparentemente", porque, em verdade, teria o constituinte se referido a duas espécies distintas de propriedade: no artigo $5^{\circ}$ referiu-se à propriedade estática, sobre a qual se falou no item anterior deste trabalho; já no artigo 170, que inaugura a ordem econômica no texto constitucional, referiu-se à propriedade dinâmica, intimamente relacionada aos bens de produção, que, por sua vez, estariam diretamente relacionados aos fins e princípios da ordem econômica. ${ }^{40}$

Esclarecendo, ao tratar da empresa e do empresário, percebe-se que o Código Civil a define como "atividade econômica organizada para a produção ou a circulação de bens ou de serviços", a partir do momento em que considera empresário aquele que exerce profissionalmente tal atividade ${ }^{41}$. No mesmo sentido estão as definições de Carla Eugênica Caldas Barros ao dispor que empresário é aquele que exerce uma "atividade econômica destinada à produção, circulação, distribuição e acumulação e criação da riqueza (...) com regras específicas para atender ao objeto de sua essência legislativa” se socorrendo do "direito civil para suprir as lacunas, também por outros olhares ramos do direito e por institutos que estão intimamente ligados a atividade econômica globalizada, ao mercado, ao consumo, a economia e a livre concorrência" ${ }^{42}$. Mais adiante o código civil também define o estabelecimento empresarial como "todo o complexo de bens organizados, para o exercício da empresa, por empresário ou sociedade empresária" (grifo nosso). ${ }^{43}$ Tal exegese explica a íntima relação afirmada entre empresa e bens de produção, clarificada pelo estabelecimento empresarial. Já a relação com a ordem econômica foi exposta linhas acima no momento em que se reconheceu na empresa a principal atividade de realização do regime econômico adotado pela Constituição.

Portanto, através da função social da propriedade dinâmica, chega-se, pelo texto constitucional, à função social da empresa, atendida através dos parâmetros presentes no artigo 170 da Constituição, o qual ambiciona o justo equilíbrio entre os princípios de

\footnotetext{
40 JÚNIOR, José Barros Correia. Função social e a responsabilidade da empresa perante os stakeholders. 2013, p. 73. Tese (Doutorado Direito) - Faculdade de Direito de Recife - FDR. Universidade Federal de Pernambuco, Pernambuco.

${ }^{41}$ BRASIL. Código Civil de 2002, Art. 966: Considera-se empresário quem exerce profissionalmente atividade econômica organizada para a produção ou a circulação de bens ou de serviços.

42 BARROS, Carla Eugênia Caldas. História do Direito Empresarial: Manual de Direito Empresarial Multifacetado. Aracaju (SE), Revista Direito da Propriedade Intelectual - Direito Contemporâneo e Constituição, Volume 1, ISBN 978-85-914737-2-4, 2014, Pág. 76

${ }^{43}$ BRASIL. Código Civil de 2002, Art. 1.142: Considera-se estabelecimento todo complexo de bens organizado, para exercício da empresa, por empresário, ou por sociedade empresária.
} 
ordem econômica liberal e de ordem política social. Registre-se que dentro do desenvolvimento da função social da propriedade, e sobretudo da empresa, enfrenta-se o desafio de melhor munir o sistema jurídico de instrumentos sancionatórios adequados ao descumprimento da função social desses institutos. Contudo, o presente trabalho não enfrenta a tarefa de contribuir necessariamente para o desenvolvimento da função social da propriedade privada e da empresa, mas apenas busca, nesse momento, uma breve compreensão de seu significado.

Assim sendo, pelo exercício da atividade empresarial, principalmente, consolidase a livre iniciativa e a livre concorrência. Sua função social é alcançada pelo respeito e efetividade da dignidade da pessoa humana, da valorização do trabalho, da justiça social, da defesa do consumidor, da defesa do meio ambiente, da redução das desigualdades social e regional, da busca pelo pleno emprego e do tratamento favorecido a pequenos empresários, almejando com isso a soberania nacional. Em suma, pelo exercício de empresa dentro dos parâmetros constitucionais, o estabelecimento, enquanto propriedade dinâmica, cumpriria sua função social.

\subsection{BENS DE PRODUÇÃO, DESTINAÇÃO SOCIAL e PROPRIEDADE INDUSTRIAL}

Como visto, chega-se à função social da empresa através da noção de propriedade dinâmica, identificada com os bens de produção em íntima relação com a ordem econômica constitucional, e enquanto estabelecimento comercial, através do qual se exerce a atividade empresarial. Porém, é necessário entender melhor a classificação dos bens de produção e sua identificação como propriedade dentro do domínio jurídico econômico. Dessa forma, espera-se uma forma de melhor entender a relação da propriedade com a empresa, bem como de suas funções sociais. A partir desse entendimento, explorar as possibilidades da propriedade industrial dentro dessa relação. Atente-se para o fato de que afirmação do instituto da função social passa pelo desenvolvimento de seus desdobramentos e particularidades, conforme cada ramo jurídico. ${ }^{44}$

\footnotetext{
${ }^{44}$ COMPARATO, Fábio Konder. Função Social da propriedade dos bens de produção. In: Revista de Direito Mercantil, n. $^{\circ}$ 63. Disponível em: PIDCC, Aracaju/Se, Ano IX, Volume 01 no 01, p.121-153 Fev/2020 | www.pidcc.com.br
} 
A função social da propriedade, viu-se, não significa restrições externas ao uso e ao gozo dos bens apropriados. Não se trata de limites negativos que oprimem os direitos do proprietário, sobretudo de domínio. A função social na verdade compõe a propriedade e conforma o exercício de tal direito dentro da complexa situação jurídica de direitos e deveres correlatos e igualmente positivos. Lições de Fábio Konder Comparato ajudam quando definem "função" como o poder-dever de dar a determinado objeto um destino, ou fazer-lhe cumprir um objetivo; e "social" como a correspondência da função ao interesse coletivo, o qual pode perfeitamente ser harmonizado com o interesse do proprietário. $^{45}$

Nesse ínterim, a destinação dada a um bem é fundamental para a sua classificação como sendo um bem de produção ou um bem de consumo. Essa classificação é, sobretudo, jurídica, e ganhou importância com a transição histórica que orientou toda a vida social para a atividade econômica de produção e distribuição de bens e serviços em massa, com o consumo cada vez mais padronizado. ${ }^{46}$ Em resumo, dentro do regime econômico moderno e adotado, a classificação entre bens de produção e bens de consumo adquire fundamental importância e está de acordo com o que se desenvolve no atual estudo.

Um bem torna-se produtivo a partir do momento em que o seu domínio passa do proprietário ao empresário, ou sociedade empresária - notadamente à figura que pratica os atos da empresa. Essa passagem marca a destinação do bem a uma exploração comercial. Pode-se dizer, no raciocínio até aqui adotado, que a propriedade passa de estática para dinâmica.

Com isso, percebe-se que uma patente, por exemplo, pode ser incorporada à atividade de exploração empresarial e ser, com isso, classificada como um bem de

https://edisciplinas.usp.br/pluginfile.php/2297584/mod_resource/content/1/COMPARATO\%2C\%20F.\%2 0C. $\% 20$ Funcao $\% 20$ social $\% 20 \mathrm{da} \% 20$ propriedade $\% 20 \mathrm{dos} \% 20$ bens $\% 20 \mathrm{de} \% 20$ producao.pdf. Acesso em: 17.07.2019.

45 COMPARATO, Fábio Konder. Função Social da propriedade dos bens de produção. In: Revista de

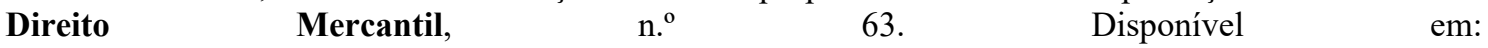
https://edisciplinas.usp.br/pluginfile.php/2297584/mod_resource/content/1/COMPARATO $\% 2$ C $\% 20$ F. $\% 2$ 0C. $\% 20$ Funcao $\% 20$ social $\% 20 \mathrm{da} \% 20$ propriedade $\% 20 \mathrm{dos} \% 20$ bens $\% 20 \mathrm{de} \% 20$ producao.pdf. Acesso em: 17.07.2019.

${ }^{46}$ COMPARATO, Fábio Konder. Função Social da propriedade dos bens de produção. In: Revista de

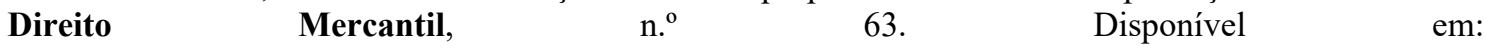
https://edisciplinas.usp.br/pluginfile.php/2297584/mod_resource/content $/ 1 /$ COMPARATO $\% 2$ C $\% 20 \mathrm{~F} . \% 2$ 0C. $\% 20$ Funcao $\% 20$ social $\% 20 \mathrm{da} \% 20$ propriedade $\% 20 \mathrm{dos} \% 20$ bens $\% 20 \mathrm{de} \% 20$ producao.pdf. Acesso em: 17.07.2019. 
produção. Porém, significa com isso dizer que a função social da propriedade industrial corresponde à função social da propriedade dos bens de produção?

Ao nosso ver, a patente, como direito, só assume seu sentido de existência dentro da lógica de produção econômica, exatamente como bem de produção, motivo pelo qual o constituinte se vale da expressão "privilégio temporário". Com isso se quer dizer que a pretensa "propriedade" industrial da patente somente existe em sua forma dinâmica, como bem de produção, sob controle do seu titular, o qual necessariamente desenvolve uma atividade econômica de exploração empresarial. A patente não deveria existir como coisa apropriada de forma estática, sob domínio de um proprietário para consumo ou gozo próprio. A compreensão constitucional desse direito, a qual se buscará no próximo tópico, evidencia a sua função social e revela essa conclusão.

\section{COMPREENSÃO CONSTITUCIONAL DA PROPRIEDADE INDUSTRIAL E SUA FUNÇÃO SOCIAL}

As doutrinas e as jurisprudências do direito civil e do direito empresarial, podese dizer com pouco risco, são mais ágeis e evoluídas em muitos pontos, se comparadas ao ramo jurídico da propriedade intelectual, sobretudo no Brasil. Uma séria de fatores contribuiu para um desenvolvimento brasileiro atrasado nos campos científico, industrial e tecnológico. Do mesmo modo, a evolução legislativa e doutrinária do ramo jurídico da propriedade intelectual enfrentou atraso e lentidão no nosso país, em que pese o país figurar como a quarta nação da história a reconhecer proteção jurídica aos inventores. ${ }^{47}$ Somado a isso, como exemplo dentro da propriedade industrial, estima-se que apenas dois por cento das patentes concedidas são objeto de litígios em todo o mundo. ${ }^{48}$

De considerações históricas, extrai-se ainda a conclusão de que o desenvolvimento de normas e proteções jurídicas para autores, inventores e financiadores

\footnotetext{
${ }^{47}$ CERQUEIRA, João da Gama. Tratado de Propriedade Industrial: da propriedade industrial e do objeto dos direitos (parte I). Atualizado por Newton Silveira e Dênis Borges Barbosa - $3^{\text {a }}$ ed. vol. I - Rio de Janeiro: Editora Lumen Juris, 2012, p. 121.

${ }^{48}$ HATTENBACH, Bem; GLUCOFT, Joshua. Patents in an era of infinite monkeys and artificial intelligence. In: Stanford Technology na Law Review, 2015, vol. 32, p. 32-51. Disponível em: https:/law.stanford.edu/wp-content/uploads/2017/10/PATENTS-IN-AN-ERA-OF-INFINITEMONKEYS-AND-ARTIFICIAL-INTELLIGENCE.pdf. Acesso em: 01.07.2019.
} 
de trabalhos criativos, é resultado de demanda gerada pelo ganho econômico e/ou interesse social que os resultados desses trabalhos passaram a adquirir. ${ }^{49}$

Os resultados em questão são bens intangíveis, imateriais e incorpóreos, dotados de certas características imanentes, como a não-exclusividade e a não-rivalidade ${ }^{50}$ - ou apenas ubiquidade $^{51}$ - as quais lhes emprestam uma espécie de imperfeição aos olhos do sistema econômico de livre mercado e livre concorrência, amplamente adotado pela grande maioria dos países. É que suas características naturais, pode-se dizer, são incompatíveis com um atributo econômico chave para o modelo de livre mercado: a escassez. Os bens intangíveis, uma vez concebidos e publicados, espalham-se instantaneamente num episódio de imediata dispersão. ${ }^{52}$

Em resumo, uma defesa do sistema de patentes se dá sob o argumento de que o desenvolvimento de invenções e o conhecimento associado envolvem frequentemente risco e incerteza significativos, enquanto o uso do conhecimento é não-rival e nãoexcludente. Com a imitação sendo mais fácil que a invenção, esse conhecimento se torna propenso a apropriações indébitas, criando um risco de colapso no mercado econômico. Sem a proteção de patentes, existe o risco de ocorrer menos atividade inventiva, tornando menos provável a divulgação de conhecimento e os benefícios ao público. ${ }^{53}$

A doutrina norte americana é sólida nesse ponto. Por exemplo, a aplicação da teoria das falhas de mercado, market failure, à compreensão da propriedade intelectual trouxe importante contribuição no sentido de demonstrar analiticamente que o modelo de mercado demanda presença de certas condições para a concretização do seu resultado ideal de alocação de recursos socialmente adequada. Retirar a escassez de bens dotados de forte e crescente valor econômico causa perturbação no ambiente de mercado,

\footnotetext{
${ }^{49}$ BARBOSA. Dênis Borges. Tratado da Propriedade Intelectual (Tomo I) $-1^{\text {a }}$ ed. - Rio de Janeiro: Editora Lumen Juris, 2013, p. 42.

50 BARBOSA. Dênis Borges. A Criação de um ambiente competitivo no campo da propriedade intelectual - o caso sul americano. Genebra: Centre for Trade and Sustainable Development (ICTSD), 2005 , p. 12.

51 ASCENSÃO, José Oliveira. A pretensa "propriedade" intelectual. In: Revista do Instituto dos Advogados de São Paulo, vol. 20/2007. São Paulo: Instituto dos Advogados de São Paulo, p. 243-261. São Paulo: Jul-Dez/2007, p. 250. Disponível em: < https:/www.passeidireto.com/arquivo/20530558/apretensa-propriedade-intelectual---jose-oliveira-ascensao >. Acesso em: 01 jun. 2019.

52 BARBOSA. Dênis Borges. A Criação de um ambiente competitivo no campo da propriedade intelectual - o caso sul americano. Genebra: Centre for Trade and Sustainable Development (ICTSD), 2005, p. 12.

${ }^{53}$ GEIGER, Christophe. Reconceptualizing the Constitutional Dimension of Intellectual Property. In: Paul L. C. Torremans (ed.), Intellectual Property and Human Rights - Information Law Series--, n. $34,3$. ed., p. 115-161. New York: 2015. Disponível em: http://www.ip.mpg.de/en/persons/dr-christophegeiger.html.
}

PIDCC, Aracaju/Se, Ano IX, Volume 01 no 01, p.121-153 Fev/2020 | www.pidcc.com.br 
retirando-lhe condições ideais para o seu ajustado funcionamento. Em tais situações, a ordem social e a ordem jurídica podem auxiliar na correção de tais perturbações, ou mesmo na introdução de certos elementos artificiais que proporcionem as condições ideais em ambientes onde elas são naturalmente inexistentes. ${ }^{54}$ Nesse ponto, adote-se a concepção de direito como produto do homem, da comunidade, com o fim de ordenar a vida humana em sociedade..$^{55}$

A propriedade intelectual, a partir dessas compreensões históricas e econômicas, figura como elemento jurídico destinado a regular a concorrência e a servir ao ambiente de mercado, no que pertinente aos bens intangíveis oriundos do esforço criativo humano. Servindo a esse propósito, acredita-se incentivar o desenvolvimento científico, cultural e tecnológico do país, cruciais para o avanço social da nação.

Essa percepção, aliada a uma crença na naturalidade da fruição humana do domínio público, dos estados da técnica e da arte, a revelar, inclusive, direitos de ordem humana e fundamental, como os de acesso à cultura, informação, saúde, educação e desenvolvimento, bem como à liberdade de expressão, levam a um entendimento dos direitos exclusivos de propriedade intelectual como sendo institutos jurídicos criados pela ordem jurídica vigente, a partir de objetivos, propósitos e conveniências políticas e econômicas, em estratégias de Estado internas e internacionais.

A adoção de tais institutos e a consagração de tais opções e interesses políticos e econômicos impõem naturalmente restrições a direitos fundamentais e liberdades públicas, como as já exemplificadas no parágrafo anterior, e como as próprias liberdades de iniciativa e concorrência, excetuadas por monopólios legais temporários de exploração. ${ }^{56}$

\footnotetext{
${ }^{54}$ GORDON, J. Wendy. Fair Use as Market Failure: A Structural and Economic Analysis of the Betamax Case and Its Predecessors, In: Columbia Law Review, 1982, n. 82, Boston, p. 1600 - 1657, Boston: Dez/1982, $\quad$ p. 1610.1 Disponível em: https://open.bu.edu/bitstream/handle/2144/22971/82ColumLRev1600_web.pdf?sequence=1\&isAllowed= y. Acesso em: 01 jun. 2019.

${ }_{55}$ MELLO, Marcos Bernardes de. Teoria do fato jurídico: plano da existência - $19^{\mathrm{a}}$ ed. - São Paulo: Saraiva, 2013, p. 33.

${ }^{56}$ Nesse ponto, importante atentar para a polissemia da palavra "monopólio" há muito afirmada porque o monopólio legal que se defende constituir os direitos de propriedade intelectual é diferente do monopólio econômico combatido pelo direito da concorrência. No monopólio econômico há a exclusividade de exploração de um mercado. Já em parte dos direitos da propriedade intelectual, a exclusividade se dá sobre um dos meios de se explorar o mercado, mas não sobre o mercado em si. A exclusividade é instrumental. Entende-se melhor quando se visualiza que o monopólio que se fala aqui é sobre novidades - requisito indispensável para a concessão dos pedidos de patentes, por exemplo - e não sobre o que já é conhecido
} 
Uma adequada interpretação do sistema constitucional brasileiro aponta para a crença do constituinte de que os objetivos e necessidades nacionais não são completamente atingidos pela integração passiva à economia mundial. Há, ao revés, a demanda por atuação política estratégica do poder público para incentivar, investir e estimular o desenvolvimento industrial e tecnológico do país em um ambiente de competição global extremamente acirrada, onde os países em desenvolvimento buscam evitar sucumbir ao enorme poderio de economias mais desenvolvidas, o que comprometeria suas autonomias nos exercícios econômico, técnico e político. É nesse contexto que figura a propriedade intelectual, como instrumento político e jurídico de incentivo à inovação e consequente desenvolvimento tecnológico. ${ }^{57}$

Então, de modo semelhante ao conceito moderno de empresa que, na ordem econômica constitucional, objetiva efetivar o justo equilíbrio entre os princípios de ordem liberal e social, a propriedade intelectual nasce como ponto de equilíbrio entre interesses distintos; como ponto de convergência de feixes de interesses e objetivos diversos. Enquanto protege os interesses materiais dos autores e inventores, dando-lhes a possibilidade de exploração temporariamente exclusiva de suas obras, objetiva fundamentalmente às finalidades coletivas de: regulação da concorrência, injetando artificialmente o atributo econômico da escassez no mercado de bens intangíveis; de incentivo e estímulo ao investimento e esforço nas atividades criativas, garantindo a presença e renovação do atributo econômico da disponibilidade no mercado; e, por fim e consequentemente, do desenvolvimento tecnológico, científico, artístico, cultural e social do país. Busca, portanto, a satisfação das necessidades nacionais e a realização dos

pelo domínio público. Assim, não se subtrai, necessariamente, algo do domínio público ou da economia, mas sim doa-se novo valor, o qual, temporariamente, terá exploração exclusiva por seu originador para então, logo após, compor definitivamente o domínio público com o livre acesso. Retarda-se o incremento de novo valor ao campo do domínio público. A concepção dos direitos intelectuais como monopólios legais, assim, tem foco estritamente econômico. A esse respeito, BARBOSA. Dênis Borges. Tratado da Propriedade Intelectual (Tomo I) $-1^{\mathrm{a}}$ ed. - Rio de Janeiro: Editora Lumen Juris, 2013, p. 104; e ASCENSÃO, José Oliveira. A pretensa "propriedade" intelectual. In: Revista do Instituto dos Advogados de São Paulo, vol. 20/2007. São Paulo: Instituto dos Advogados de São Paulo, p. 243-261. São Paulo: Jul-Dez/2007, p. 247. Disponível em: https://www.passeidireto.com/arquivo/20530558/a-pretensapropriedade-intelectual---jose-oliveira-ascensao. Acesso em: 01 jun. 2019.

${ }^{57}$ ARRUDA, Mauro Fernando Maria. Desenvolvimento Tecnológico da Indústria e a Constituição de um Sistema Nacional de Inovação no Brasil. Coordenação: Prof. Dr. Luciano G.Coutinho, Prof. Dr. Wilson Suzigan, Dênis Borges Barbosa / Mauro Fernando Maria Arruda. Campinas: Universidade Estadual de Campinas - Instituto de Economia - Centro de estudos de ralações econômicas internacionais - Núcleo de Economia Industrial e da Tecnologia, 1990, p. 6-7. Disponível em: http://denisbarbosa.addr.com/Sobre\%20a\%20Propriedade\%20Intelectual.pdf. Acesso em: 01 jun. 2019. 
objetivos e valores sociais, constitucionalmente consagrados, através do avanço científico, tecnológico e cultural. ${ }^{58}$

Seguindo com a compreensão nesse sentido, dada à base de considerações históricas, costuma-se reconhecer um maior peso ao interesse público no usufruto do conhecimento, em comparação ao interesse particular de exploração econômica do esforço intelectivo. É que, originariamente, constata-se tais privilégios funcionando como exceção à regra do domínio público de acesso ao conhecimento e tecnologia gerados pela humanidade, e que eram, em origem, concedidos exclusivamente pelo monarca, a seu critério. $^{59}$

Assim é que a parte final do inciso XXIX, do artigo $5^{\circ}$ da Constituição, pertinente à propriedade industrial, expressa o que se convencionou chamar de "função social da propriedade industrial". ${ }^{60}$ Já no inciso XXVII, pertinente aos direitos autorais, o constituinte não expressou um conteúdo semelhante em sua redação. No entanto, por meio de uma interpretação sistemática a partir da compreensão da natureza jurídica do complexo de direito intelectuais, bem como da construção da propriedade intelectual como sistema que abriga os direitos autorais, a propriedade industrial e ainda direitos conexos, chega-se à mesma interpretação contida de modo expresso no dispositivo constitucional referente à propriedade industrial. ${ }^{61}$

Tem-se, também, que a propriedade industrial possui natureza manifestadamente patrimonial e econômica, como bem unicamente produtivo. Sua categoria de vinculação é, portanto, indiscutivelmente, a dos direitos reais, como coisa. A ela o constituinte se

\footnotetext{
${ }^{58}$ BARBOSA. Dênis Borges. Tratado da Propriedade Intelectual (Tomo I) - $1^{\text {a }}$ ed. - Rio de Janeiro: Editora Lumen Juris, 2013, p. 73.

${ }^{59}$ CERQUEIRA, João da Gama. Tratado de Propriedade Industrial: da propriedade industrial e do objeto dos direitos (parte I). Atualizado por Newton Silveira e Dênis Borges Barbosa - $3^{\mathrm{a}}$ ed. vol. I - Rio de Janeiro: Editora Lumen Juris, 2012, p. 54-55.

${ }^{60}$ BRASIL. Constituição Federal de 1988, Art. $5^{\circ}$ : todos são iguais perante a lei, sem distinção de qualquer natureza, garantindo-se aos brasileiros e aos estrangeiros residentes no País a inviolabilidade do direito à vida, à liberdade, à igualdade, à segurança e à propriedade, nos termos seguintes: [...] XXVII - aos autores pertence o direito exclusivo de utilização, publicação ou reprodução de suas obras, transmissível aos herdeiros pelo tempo que a lei fixar; [...] XXIX - a lei assegurará aos autores de inventos industriais privilégio temporário para sua utilização, bem como proteção às criações industriais, à propriedade das marcas, aos nomes de empresas e a outros signos distintivos, tendo em vista o interesse social e o desenvolvimento tecnológico e econômico do País (grifo nosso).

${ }^{61}$ SOUZA, Allan Rocha de. Os limites dos Direitos Autorais: uma interpretação civil-constitutcional dos limites da proteção jurídica In: Anais do XV Encontro Preparatório para o Congresso Nacional do CONPEDI - Tema: "Direitos Fundamentais e Sociedade Contemporânea" -, 2006, p. 1956-1977. Campos dos Goytacazes: Faculdade de Direito de Campos, 2006. Disponível em: https://www.conpedi.org.br/quemsomos/eventos/. Acesso em: 26/10/2017.
} 
refere com o uso das expressões "direito exclusivo de utilização, publicação ou reprodução" (grifo nosso), e "privilégio temporário para sua utilização" (grifo nosso), nos incisos XXVII e XIX, respectivamente.

Por estas e outras razões, como muito bem asseveram Mallmann e Melo " a tutela jurídica conferida à propriedade intelectual é de fundamental importância para o desenvolvimento tecnológico e econômico do país. Sem a proteção conferida pelo direito, não haveria estímulos para que o resultado da atividade criativa do homem fosse levado à público, ou mesmo para que houvesse o necessário investimento de tempo e recursos financeiros para o desenvolvimento de novas ideias. Não é por outra razão que a Constituição Federal, em seu art. $5^{\circ}$, XXIX, alça o direito à Propriedade Intelectual ao status de Direito Fundamental",62.

No entanto, sabe-se que a acepção "propriedade" possui sentido ambíguo mesmo no plano jurídico, ${ }^{63}$ não sendo de todo incomum ou inadequado a sua utilização para denominar o conjunto de direitos patrimoniais (reais) como um todo, já que ostenta status de direito real máximo. Para Dênis Borges Barbosa e José Oliveira Ascensão, a referência aos direitos intelectuais exclusivos como sendo direitos de propriedade se deve a esse sentido mais amplo da palavra. Além do que, a característica chave da propriedade de oponibilidade erga omnes se faz presente também nos direitos exclusivos, ainda que de modo temporário. ${ }^{64}$

Os direitos de propriedade, como demonstrado no tópico anterior, se encontram indiscutivelmente funcionalizados à sua finalidade social pela Constituição Federal de 1988, onde o inciso XXIII, do artigo 5a , da Carta, dispõe que "a propriedade atenderá a sua função social". O sentido constitucional da propriedade, na acepção ampla de conjunto de direitos de alcance patrimonial, permite concluir que todos os direitos patrimoniais deverão submeter-se a função social de que fala o dispositivo constitucional mencionado. Pelo desenvolvimento até aqui realizado, viu-se também

\footnotetext{
${ }^{62}$ MALLMANN, Querino \& MELO, Pedro José Costa. A Ação Coletiva Passiva para a Tutela de Patentes. In Revista de Direito da Propriedade Intelectual - Direito Contemporâneo e Constituição (PIDCC), Aracaju (SE), Volume $09 \mathrm{n}^{\mathrm{O}}$ 02, ano IV, Jun/2015, pág. 57.

63 ASCENSÃO, José Oliveira. A pretensa "propriedade" intelectual. In: Revista do Instituto dos Advogados de São Paulo, vol. 20/2007. São Paulo: Instituto dos Advogados de São Paulo, p. 243-261. São Paulo: Jul-Dez/2007, p. 246. Disponível em: https://www.passeidireto.com/arquivo/20530558/apretensa-propriedade-intelectual---jose-oliveira-ascensao. Acesso em: 26/10/2017.

${ }^{64}$ COMPARATO, Fábio Konder. Função Social da propriedade dos bens de produção. In: Revista de Direito Mercantil, n. $^{\circ} 63.6$ Disponível https://edisciplinas.usp.br/pluginfile.php/2297584/mod_resource/content/1/COMPARATO\%2C\%20F.\%2 0C.\%20Funcao\%20social\%20da\%20propriedade $\% 20$ dos $\% 20$ bens $\% 20 \mathrm{de} \% 20$ producao.pdf. Acesso em: 17.07.2019.
} 
que a função social da propriedade é também prevista no artigo 170 da Constituição, dessa vez referindo-se à propriedade dinâmica dos bens de produção, dentro os quais deve-se ter incluída a compreensão da propriedade industrial.

Da análise das justificações e construção da propriedade intelectual, constata-se que o bem jurídico fundamentalmente tutelado é o interesse coletivo ${ }^{65}$ e os propósitos políticos e econômicos representados pela regulação da concorrência em torno dos bens incorpóreos, incentivo ao investimento financeiro e laboral nos trabalhos criativos e inventivos, de modo a estimular o desenvolvimento tecnológico, científico e cultural do país. Esse é o conteúdo material contido nas normas de propriedade intelectual; é, portanto, o efeito pretendido pelas normas desse subsistema.

A leitura da parte final do texto do inciso XXIX, artigo $5^{\circ}$, guarda exata correspondência com o conteúdo material dos direitos intelectuais, revelado pela sua compreensão teleológica. A elogiar, não poderia ter sido mais feliz o constituinte na redação desse dispositivo. Logo, a função social da propriedade intelectual, a exemplo do que se vem construindo dentre os demais ramos jurídicos das relações privadas, não seria necessariamente restrições externas aos direitos exclusivos, como foi visto na função social da propriedade privada, mas sim a positivação expressa do seu conteúdo material, da sua carga de eficácia e das suas bases de justificação.

Os institutos jurídicos, em consagrada classificação, decompõem-se em dois elementos: o elemento estrutural e o elemento teleológico ou funcional; em outras palavras, a estrutura e a função. A função corresponde aos interesses que um certo instituto pretende tutelar, e é, na verdade, o seu elemento de maior importância já que determina, em última análise, os traços fundamentais da estrutura. ${ }^{66}$

O constituinte, na feliz redação formulada, aclarou o sentido que se chegaria, inevitavelmente, através da interpretação teleológica a ser empreendida pelo intérprete.

\footnotetext{
${ }^{65}$ GOMES, Rita de Cássia Medeiros. O direito e a propriedade intelectual: constitucionalização, campo de atuação e responsabilidade a violação do direito. In: Revista de Propriedade Intelectual, Direito Contemporâneo e Constituição - PIDCC - Aracaju/SE, Ano IX, Vol. 01, nº 01, p. 060-082, Fev/2020. P. 70. Disponível em: http://pidcc.com.br/br/component/content/article/2-uncategorised/371-o-direito-e-apropriedade-intelectual-constitucionalizacao-campo-de-atuacao-e-responsabilidade-a-violacao-do-direito. Acesso em: 26.02.2020.

${ }^{66}$ TEPEDINO, Gustavo; SCHREIBER, Anderson. A garantia da propriedade no direito brasileiro. In: Revista da Faculdade de Direito de Campos, Ano VI, no 6, Junho de 2005, p. 101-120. Disponível em: http://fdc.br/Arquivos/Mestrado/Revistas/Revista06/Docente/04.pdf. Acesso em: 17.07.2019.
} 
Optou por contribuir, então, para evitar dúvidas quanto ao fim buscado pela propriedade intelectual. A função social, então, serve à fundamental tarefa de se iluminar o alcance e extensão dos direitos intelectuais, obstando uma interpretação excessivamente privatista que foque nos interesses secundários e particulares dos titulares de exclusivas, em desfavor aos interesses coletivos, primários e medulares, que sustentam e balizam oo sistema de propriedade intelectual.

Com isso, caso haja uma concretização das tensões havidas entre os interesses diversos que compuseram a construção da propriedade intelectual, tendo clara a sua compreensão, bem como as suas bases de justificação, o intérprete se verá diante de um conflito entre interesses "meios" e interesses "fins"; entre objetivos secundários e objetivos primários.

Em tais situações, Ana Paula de Barcellos instrui que "se existem fins, e há meios para alcança-los, e se, em determinadas circunstâncias, os meios conflitam com os próprios fins que buscam realizar, não se deve privilegiar o meio em detrimento do fim". ${ }^{67}$ Reafirma-se que a função social não impõe restrições aos direitos exclusivos, ela apenas revela o conteúdo material do enunciado normativo. Se a função social não está sendo atendida, significa que o conteúdo material não incide no caso concreto e a carga de eficácia contida no enunciado normativo não está sendo realizada na norma invocada, logo seu exercício não se justifica.

O mecanismo sancionatório para o descumprimento da função social da propriedade industrial de patentes é a chamada licença compulsória, aplicável em hipótese de o titular da patente "exercer os direitos dela decorrentes de forma abusiva, ou por meio dela praticar abuso de poder econômico". No entanto, o parágrafo primeiro do mesmo artigo prevê ainda que a licença compulsória será aplicada na "falta de fabricação ou fabricação incompleta do produto, ou, ainda, a falta de uso integral do processo patenteado, ressalvados os casos de inviabilidade econômica, quando será admitida a importação"; ou ainda quando a comercialização não satisfazer as necessidades do mercado. ${ }^{68}$

\footnotetext{
${ }^{67}$ BARCELLOS, Ana Paula de. Ponderação, racionalidade e atividade jurisdicional - Rio de Janeiro: Renovar, 2005, p. 245.

${ }^{68}$ BRASIL. Lei 9.279/96, Art. 68: O titular ficará sujeito a ter a patente licenciada compulsoriamente se exercer os direitos dela decorrentes de forma abusiva, ou por meio dela praticar abuso de poder econômico, comprovado nos termos da lei, por decisão administrativa ou judicial.
} 
Nas últimas duas hipóteses de licença compulsória, a Lei de Propriedade Industrial evidencia a conclusão que aqui se defende. A patente, como direito, só assume seu sentido de existência dentro da lógica de exploração econômica, como um bem de produção, nunca de consumo. Com isso se quer dizer que a pretensa "propriedade" industrial da patente somente existe em sua forma dinâmica, como bem produtivo, sob controle do seu titular, o qual necessariamente desenvolve uma atividade econômica de exploração empresarial.

Há ainda a hipótese de licenciamento compulsório do artigo 71, para os casos de emergência nacional ou interesse público, que deverão ser declarados em ato do Poder Executivo Federal, desde que o titular da patente ou seu licenciado não atenda a essa necessidade. ${ }^{69}$ Ou seja, a lei ainda põe ressalvada a chance de o interesse púbico ou emergência nacional que motivaria a licença compulsória ser atendido pela exploração do próprio titular da patente, ou seu licenciado, pela exploração legítima de seu direito. Tal ressalva reforça a crença do constituinte de que os interesses coletivos podem e preferencialmente devem ser atendidos a partir do sistema de patentes construído justamente para essa finalidade, tal qual demonstra a compreensão trazida no presente estudo.

Por fim, atenta-se para o fato de que a licença compulsória será sempre não exclusiva, não se admitindo o sublicenciamento. ${ }^{70} \mathrm{Ou}$ seja, a "quebra de patente", como vulgarmente é chamada a licença compulsória, uma vez motivada, importa na não realização dos objetivos primários do sistema de patentes, que lhe servem de alicerces de legitimação. Logo, o objeto da patente compulsoriamente licenciada não poderá ser explorado sob a forma de privilégio temporário exclusivamente assenhorado por um outro particular.

\section{CONCLUSÃO}

\footnotetext{
${ }^{69}$ BRASIL. Lei 9.279/96, Art. 71: Nos casos de emergência nacional ou interesse público, declarados em ato do Poder Executivo Federal, desde que o titular da patente ou seu licenciado não atenda a essa necessidade, poderá ser concedida, de ofício, licença compulsória, temporária e não exclusiva, para a exploração da patente, sem prejuízo dos direitos do respectivo titular.

${ }^{70}$ BRASIL. Lei 9.279/96, Art. 72: As licenças compulsórias serão sempre concedidas sem exclusividade, não se admitindo o sublicenciamento. $\mathrm{O}$ titular ficará sujeito a ter a patente licenciada compulsoriamente se exercer os direitos dela decorrentes de forma abusiva, ou por meio dela praticar abuso de poder econômico, comprovado nos termos da lei, por decisão administrativa ou judicial.
} 
Diante do exposto conclui-se que a constitucionalização do direito privado é resultado de uma nova formatação do sistema jurídico que redefine os papeis e posições da Constituição e do Código Civil. A primeira desbanca o segundo da posição que historicamente ocupou e passa a ocupar o ponto mais alto do ordenamento jurídico, com suas disposições assumindo definitivamente o caráter normativo para, assim, irradiar seus valores e objetivos por todo o sistema jurídico. Nesse cenário, os principais pilares do direito privado passam por releituras e, pode-se dizer também, reconstruções na doutrina e na jurisprudência.

Uma releitura do direito de propriedade atingiu nuclearmente a sua função, e, com isso, redefiniu a sua estrutura. Passa a compor o direito de propriedade uma função social que a ele não se opõe, de modo a negar a sua existência e esvaziar o seu conteúdo, oprimindo o seu exercício por parte do proprietário. Na verdade, a função social se insere na complexa ideia de que o reconhecimento de um direito implica necessariamente o reconhecimento de um dever correlato. Logo, o direito fundamental de propriedade provoca a existência de deveres fundamentais a ele relacionados.

Então, a função social compõe o direito de propriedade, não havendo contraposição. Ela implica no reconhecimento de interesses metaindividuais a serem satisfeitos pelo exercício do direito de propriedade, ao lado das já consagradas garantias individuais do proprietário. Assim, o sujeito de direito, no uso, gozo e disposição de seu bem, deverá satisfazer seus interesses de um modo atento aos interesses sociais, contribuindo, assim, para a sua realização. O proprietário permanece como titular do direito de propriedade e beneficiário imediato das prerrogativas desse direito, condição que o torna titular também dos deveres e ônus intersubjetivamente relacionados com o direito de propriedade.

O reconhecimento da função social da propriedade importa no reconhecimento da escolha do constituinte brasileiro por um regime econômico de livre mercado. No regime econômico de livre mercado, a propriedade privada é imprescindível, assim como o regime livre de trocas que tem nos contratos a sua forma jurídica mais axiomática. Nesse ambiente, a empresa figura como a atividade econômica que guarda, justamente, a finalidade principal de produção e circulação de bens e serviços. A empresa é, portanto, e por definição, a principal atividade de realização do regime econômico de livre mercado, adotado pela ordem constitucional brasileira, e é na empresa que a função social da propriedade mais se destaca. Seu exercício se realiza através da organização de bens 
de produção, que compõem o estabelecimento comercial, segundo o artigo 1.142 do Código Civil, enquanto propriedade dinâmica.

Através da função social da propriedade dinâmica, chega-se, pelo texto constitucional, à função social da empresa, atendida através dos parâmetros presentes no artigo 170 da Constituição, o qual ambiciona o justo equilíbrio entre os princípios de ordem econômica liberal e de ordem política social. Pelo exercício da atividade empresarial, principalmente, consolida-se a livre iniciativa e a livre concorrência. A função social da empresa é alcançada com o respeito e efetivação da dignidade da pessoa humana, da valorização do trabalho, da justiça social, da defesa do consumidor, da defesa do meio ambiente, da redução das desigualdades social e regional, da busca pelo pleno emprego e do tratamento favorecido a pequenos empresários, almejando com isso a soberania nacional. Em suma, pelo exercício de empresa dentro dos parâmetros constitucionais, o estabelecimento, enquanto propriedade dinâmica, cumpriria sua função social.

A destinação dada a um bem é fundamental para a sua classificação como sendo um bem de produção ou de consumo. Essa classificação é, sobretudo, jurídica, e ganhou importância com a transição histórica que orientou toda a vida social para a atividade econômica de produção e distribuição de bens e serviços em massa, com o consumo cada vez mais padronizado.

Um bem torna-se produtivo a partir do momento em que o seu domínio passa do proprietário ao empresário, ou sociedade empresária - notadamente à figura que pratica os atos da empresa. Essa passagem marca a destinação do bem a uma exploração comercial. Pode-se dizer, no raciocínio até aqui adotado, que a propriedade passa de estática para dinâmica. Com isso, percebe-se que uma patente, por exemplo, pode ser incorporada à atividade de exploração empresarial e ser, com isso, classificada como um bem de produção.

A propriedade intelectual, a partir de compreensões históricas e econômicas, figura como elemento jurídico destinado a regular a concorrência e servir ao ambiente de mercado, no que pertinente aos bens intangíveis oriundos do esforço criativo humano. Tal percepção, aliada a uma crença na naturalidade da fruição humana do domínio público, dos estados da técnica e da arte, a revelar, inclusive, direitos de ordem humana ou 
fundamental, como os de acesso à cultura, informação, saúde, educação e desenvolvimento, bem como a liberdade de expressão, levam a um entendimento dos direitos exclusivos de propriedade intelectual como sendo institutos jurídicos criados pela ordem jurídica vigente, a partir de objetivos, propósitos e conveniências políticas e econômicas, em estratégias internas e internacionais.

A adoção de tais institutos e a consagração de tais opções e interesses políticos e econômicas, impõe naturalmente restrições a direitos fundamentais e liberdades públicas, como as que foram exemplificadas no parágrafo acima, e como a própria liberdade de iniciativa e concorrência.

Dessa forma, a propriedade intelectual nasce como ponto de equilíbrio entre interesses distintos; como ponto de convergência de feixes de interesses e objetivos diversos. Enquanto protege os interesses materiais dos autores e inventores, dando-lhes a possibilidade de exploração temporariamente exclusiva de suas obras, objetiva em verdade: a regulação da concorrência, injetando artificialmente o atributo econômico da escassez no mercado de bens intangíveis; o incentivo e estímulo ao investimento e esforço nas atividades criativas, garantindo a presença e renovação do atributo econômico da disponibilidade no mesmo mercado; e, por fim e consequentemente, o desenvolvimento tecnológico, científico, artístico, cultural e social do país. Busca, portanto, a satisfação das necessidades nacionais e a realização dos objetivos e valores sociais, constitucionalmente consagrados, através do avanço científico, tecnológico e cultural.

Dessas conclusões se extrai a exata compreensão da construção da propriedade intelectual, de suas bases de justificação e dos interesses que visa fundamentalmente tutelar; chega-se, portanto, à função desses direitos. Com tal análise funcionalizada, interpreta-se a parte final do texto do inciso XXIX, artigo $5^{\circ}$, como uma exata correspondência ao conteúdo material dos direitos intelectuais, revelado pela sua compreensão teleológica. A elogiar, não poderia ter sido mais feliz o constituinte na redação desse dispositivo.

Logo, a função social da propriedade intelectual, a exemplo do que se vem construindo dentre os demais ramos jurídicos das relações privadas, não seria necessariamente restrições externas aos direitos exclusivos, assim como ocorre na função social da propriedade privada, mas sim a positivação expressa do seu conteúdo material, da sua carga de eficácia e das suas bases de justificação. 
A função social, então, serve à fundamental tarefa de se iluminar o alcance e extensão dos direitos intelectuais, obstando uma interpretação excessivamente privatista que foque nos interesses secundários e particulares dos titulares de exclusivas, em desfavor aos interesses coletivos, primários e medulares, que sustentam e balizam o sistema de propriedade intelectual.

A análise funcionalizada do direito de patente, revela que sua existência somente assume sentido dentro da lógica de produção econômica, exatamente como bem de produção, motivo pelo qual o constituinte se vale da expressão "privilégio temporário". Com isso se quer dizer que a pretensa "propriedade" industrial da patente somente existe em sua forma dinâmica, como bem de produção, sob controle do seu titular, o qual necessariamente desenvolve uma atividade econômica de exploração empresarial. A patente nunca irá existir como coisa apropriada na forma estática, sob domínio de um proprietário para consumo ou gozo próprio. A compreensão constitucional e funcionalizada desse direito evidencia a sua função social de modo a revelar essa conclusão.

\section{REFERÊNCIAS BIBLIOGRÁFICAS}

ALMEIDA, Maria Christina de. A função social da empresa na sociedade contemporânea: perspectivas e prospectivas. In: Argumentum - Revista de Direito n.3 2003 - UNIMAR. Disponível em: http://ojs.unimar.br/index.php/revistaargumentum/article/viewFile/697/348. Acesso em: 17.07.2019.

ARRUDA, Mauro Fernando Maria. Desenvolvimento Tecnológico da Indústria e a Constituição de um Sistema Nacional de Inovação no Brasil. Coordenação: Prof. Dr. Luciano G.Coutinho, Prof. Dr. Wilson Suzigan, Dênis Borges Barbosa / Mauro Fernando Maria Arruda. Campinas: Universidade Estadual de Campinas - Instituto de Economia Centro de estudos de ralações econômicas internacionais - Núcleo de Economia Industrial e da Tecnologia, 1990, p. 6-7. Disponível em: http://denisbarbosa.addr.com/Sobre\%20a\%20Propriedade\%20Intelectual.pdf. Acesso em: 01 jun. 2019.

ASCENSÃO, José Oliveira. A pretensa “propriedade” intelectual. In: Revista do Instituto dos Advogados de São Paulo, vol. 20/2007. São Paulo: Instituto dos Advogados de São Paulo. São Paulo: Jul-Dez/2007, p. 250. Disponível em: < 
https://www.passeidireto.com/arquivo/20530558/a-pretensa-propriedade-intelectual--jose-oliveira-ascensao >. Acesso em: 01 jun. 2019.

BARBOSA. Dênis Borges. Tratado da Propriedade Intelectual (Tomo I) $-1^{\mathrm{a}}$ ed. - Rio de Janeiro: Editora Lumen Juris, 2013.

BARBOSA. Dênis Borges. A Criação de um ambiente competitivo no campo da propriedade intelectual - o caso sul americano. Genebra: Centre for Trade and Sustainable Development (ICTSD), 2005.

BARCELLOS, Ana Paula de. Ponderação, racionalidade e atividade jurisdicional - Rio de Janeiro: Renovar, 2005.

BARROS, Carla Eugênia Caldas. História do Direito Empresarial: Manual de Direito Empresarial Multifacetado. Aracaju (SE), Revista Direito da Propriedade Intelectual Direito Contemporâneo e Constituição, Volume 1, ISBN 978-85-914737-2-4, 2014

BARROSO, Luís Roberto. Curso de direito constitucional contemporâneo: os conceitos fundamentais e a construção do novo modelo - $4^{\mathrm{a}}$ ed. - São Paulo: Saraiva, 2013.

BARROSO, Luís Roberto. A razão sem voto: o Supremo Tribunal Federal e o governo da maioria. In: A razão sem voto: diálogos constitucionais com Luís Roberto Barroso org. Oscar Vilhena Vieira e Rubens Glezer. São Paulo: Saraiva, 2017.

BRASIL, Constituição da República Federativa do Brasil: promulgada em 22 de setembro de $1988 . \quad$ Disponível em: http://www.planalto.gov.br/ccivil_03/constituicao/constituicaocompilado.htm.

BRASIL, Código Civil, Lei n ${ }^{\circ}$ 10.406: promulgada em 10 de janeiro de 2002. Disponível em: http://www.planalto.gov.br/ccivil_03/constituicao/constituicaocompilado.htm.

BRASIL, Lei de Propriedade Industrial, $n^{\circ}$ 9.279: promulgada em 14 de maio de 1996. Disponível em: http://www.planalto.gov.br/ccivil_03/leis/L9279.htm.

CERQUEIRA, João da Gama. Tratado de Propriedade Industrial: da propriedade industrial e do objeto dos direitos (parte I). Atualizado por Newton Silveira e Dênis Borges Barbosa - 3 ${ }^{\mathrm{a}}$ ed. vol. I - Rio de Janeiro: Editora Lumen Juris, 2012.

COMPARATO, Fábio Konder. Direitos e deveres fundamentais em matéria de propriedade. In: Revista CEJ, Vol. 1, n. 3, set./dez, 1997. Disponível em: http://www.jf.jus.br/ojs2/index.php/revcej/article/view/123/166. Acesso em: 17.07.2019.

COMPARATO, Fábio Konder. Função Social da propriedade dos bens de produção. In: Revista de Direito Mercantil, n. ${ }^{\circ}$ 63. Disponível em: https://edisciplinas.usp.br/pluginfile.php/2297584/mod_resource/content/1/COMPARA TO $\% 2$ C $\% 20$ F. $\% 20$ C. $\% 20$ Funcao $\% 20$ social $\% 20$ da $\% 20$ propriedade $\% 20$ dos $\% 20$ bens $\% 2$ 0de\%20producao.pdf. Acesso em: 17.07.2019.

GEIGER, Christophe. Reconceptualizing the Constitutional Dimension of Intellectual Property. In: Paul L. C. Torremans (ed.), Intellectual Property and Human Rights - 
Information Law Series-, n. 34, 3. ed., p. 115-161. New York: 2015. Disponível em: http://www.ip.mpg.de/en/persons/dr-christophe-geiger.html.

GOMES, Rita de Cássia Medeiros. $\mathrm{O}$ direito e a propriedade intelectual: constitucionalização, campo de atuação e responsabilidade a violação do direito. In: Revista de Propriedade Intelectual, Direito Contemporâneo e Constituição - PIDCC Aracaju/SE, Ano IX, Vol. 01, no 01, p. 060-082, Fev/2020. P. 70. Disponível em: http://pidcc.com.br/br/component/content/article/2-uncategorised/371-o-direito-e-apropriedade-intelectual-constitucionalizacao-campo-de-atuacao-e-responsabilidade-aviolacao-do-direito.

GORDON, J. Wendy. Fair Use as Market Failure: A Structural and Economic Analysis of the Betamax Case and Its Predecessors, In: Columbia Law Review, 1982, n. 82, Boston, p. 1600 - 1657, Boston: Dez/1982, p. 1610. Disponível em: https://open.bu.edu/bitstream/handle/2144/22971/82ColumLRev1600_web.pdf?sequenc $\mathrm{e}=1$ \&isAllowed=y. Acesso em: 01 jun. 2019.

GRAU, Eros Roberto. A ordem econômica na Constituição de 1988. São Paulo: Malheiros, 2000.

HATTENBACH, Bem; GLUCOFT, Joshua. Patents in an era of infinite monkeys and artificial intelligence. In: Stanford Technology na Law Review, 2015, vol. 32, p. 32-51. Disponível em: https://law.stanford.edu/wp-content/uploads/2017/10/PATENTS-INAN-ERA-OF-INFINITE-MONKEYS-AND-ARTIFICIAL-INTELLIGENCE.pdf.

Acesso em: 01.07.2019.

JÚNIOR, José Barros Correia. Função social e a responsabilidade da empresa perante os stakeholders. 2013. Tese (Doutorado Direito) - Faculdade de Direito de Recife - FDR. Universidade Federal de Pernambuco, Pernambuco.

KRELL, Andreas Joachim. Entre desdém teórico e aprovação na prática: os métodos clássicos de interpretação jurídica. In: Revista de Direito GV. São Paulo, vol. 10 n. 1, jan/jun, 2014, p. 295-320.

LÔBO, Paulo. Direito Civil: parte geral - $4^{\mathrm{a}}$ ed. - São Paulo: Saraiva, 2013.

LÔBO, Paulo. Novas perspectivas da constitucionalização do direito civil. Jus Navigandi, Teresina, ano 18 (/revista/edições/2013). Disponível em: $<$ http://jus.com.br/artigos/25361>. Acesso em: 01 jun. 2019.

LÔBO, Paulo. Metodologia do Direito Civil Constitucional. In: Direito Civil Constitucional - A ressignificação da função dos institutos fundamentais do direito civil contemporâneo e sua consequências / Organizadores: Carlos Eduardo Pianovski Ruzyk; Eduardo Nunes de Souza; Joyceane Bezerra de Menezes; Marcos Ehrhardt Junior Florianópolis: Conceito Editorial, 2014. P. 19-31; e TEPEDINO, Gustavo. Premissas metodológicas para a constitucionalização do Direito Civil. In: RDE - Revista de Direito do Estado, ano 1, no 2:37-53, abr/jun 2006, p. 37-53. Disponível em: http://www.tepedino.adv.br/wpp/wp- 
content/uploads/2017/07/Premissas_metodologicas_constitucionalizacao_Direito_Civil _fls_37-53.pdf. Acesso em 01.07.2019.

MALLMANN, Querino \& MELO, Pedro José Costa. A Ação Coletiva Passiva para a Tutela de Patentes. In Revista de Direito da Propriedade Intelectual - Direito Contemporâneo e Constituição (PIDCC), Aracaju (SE), Volume 09 nº 02, ano IV, Jun/2015

MELLO, Marcos Bernardes de. Teoria do fato jurídico: plano da existência $-19^{\mathrm{a}}$ ed. São Paulo: Saraiva, 2013.

MORAES, Maria Celina Bodin de. A constitucionalização do direito civil e seus efeitos sobre a responsabilidade civil. In: A constitucionalização do direito: fundamentos teóricos e aplicações específicas - org. Cláudio Pereira de Souza Neto e Daniel Sarmento - Rio de Janeiro: Lumen Juris, 2007, p. 233-258.

ROCHA, José Cláudio; ALVES, Aliana; SANTOS, Gilberto Batista. Direito Contemporâneo, propriedade intelectual e o novo marco legal para a ciência, tecnologia e inovação. In: Revista de Propriedade -Intelectual, Direito Contemporâneo e Constituição - PIDCC - Aracaju/SE, Ano VIII, Vol. 13, nº 03, p. 187-206, Out/2019. P. 203. Disponível em: http://pidcc.com.br/br/component/content/article/2uncategorised/364-direito-contemporaneo-propriedade-intelectual-e-o-novo-marcolegal-para-a-ciencia-tecnologia-e-inovacao.

SARMENTO, Daniel. Direitos fundamentais e relações privadas $-2^{a}$ ed., 3.tir. - Rio de Janeiro: Lumen Juris, 2010.

SCHREIBER, Anderson. Função social da propriedade na prática jurisprudencial brasileira, p. 03. Disponível em: http://sdls.com.br/uploads/files/2018/06/funcao-socialda-propriedade-na-pratica-jurisprudencial-brasileira.pdf. Acesso em: 17.07.2019.

SILVA, Juliana Giovanetti Pereira da. A publicização do Direito Comercial e a função social da empresa. Revista de Direito Empresarial - RDEmp, Belo Horizonte, ano 12, n. 1, p. 215-229, jan./abr. 2015.

SOUZA, Allan Rocha de. Os limites dos Direitos Autorais: uma interpretação civilconstitutcional dos limites da proteção jurídica In: Anais do XV Encontro Preparatório para o Congresso Nacional do CONPEDI - Tema: "Direitos Fundamentais e Sociedade Contemporânea" -, 2006, p. 1956-1977. Campos dos Goytacazes: Faculdade de Direito de Campos, 2006. Disponível em: https:/www.conpedi.org.br/quemsomos/eventos/. Acesso em: 26/10/2017.

TEPEDINO, Gustavo. Premissas metodológicas para a constitucionalização do Direito Civil. In: RDE - Revista de Direito do Estado, ano 1, no 2:37-53, abr/jun 2006, p. 37-53. Disponível em: http:/www.tepedino.adv.br/wpp/wpcontent/uploads/2017/07/Premissas_metodologicas_constitucionalizacao_Direito_Civil _fls_37-53.pdf. Acesso em 01.07.2019.

TEPEDINO, Gustavo. A proteção da boa-fé na propriedade industrial. Revista Brasileira de Direito Civil - RBDCivil, Belo Horizonte, v. 18, p. 199-215, out./ dez. 2018. Parecer. 
ANÁLISE FUNCIONAL DA PROPRIEDADE INDUSTRIAL NAS RELAÇÕES EMPRESARIAIS

CONTEMPORÂNEAS

E-ISSN 2316-8080

TEPEDINO, Gustavo; SCHREIBER, Anderson. A garantia da propriedade no direito brasileiro. In: Revista da Faculdade de Direito de Campos, Ano VI, $n^{\circ}$ 6, Junho de 2005, p. $101-120$.

Disponível

em:

http://fdc.br/Arquivos/Mestrado/Revistas/Revista06/Docente/04.pdf. Acesso em: 17.07.2019.

TOLEDO, Gastão Alves de. O direito constitucional econômico e sua eficácia - Rio de Janeiro: Renovar, 2004. 